\author{
Aleksander Polonnikow \\ Białoruski Uniwersytet Państwowy w Mińsku \\ alexpolonnikov@gmail.com
}

\title{
Symboliczne praktyki edukacji. Doświadezenie A.S. Makarenki w postsocjalistycznym dyskursie pedagogicznym
}

\section{Summary}

Symbolic practices of education. A.S. Makarenko's experience in the post-socialist pedagogical discourse

The problem discussed in the article is related to the attitude to the pedagogical tradition born in conditions of the formation and development of the totalitarian society. Its reconstruction and analysis is organized by denoting this experience in the form of text. In this context the relation to tradition gains an intertextual character, constructed by it being referred to the context of modernity. The key function of such contextualisaion is the so-called re-symbolization. Three strategies of resymbolization are described, namely "iconoclastic", "iconomanic", and "social-constructionistic". They all, to some extent, are present in the pedagogical discourse of the post-socialist communities. The former two strategies are oriented at the "truth" of the tradition, whereas the third strategy considers is as an interpretive and practical category. Analyzed is the structural-functional organization of the three strategies of resymbolization.

Keywords: Makarenko's experience, pedagogical discourse, strategies of resymbolization, tactics of resymbolization, design of communication environment, null value

Słowa kluczowe: doświadczenie Makarenki, pedagogiczny dyskurs, strategie resymbolizacji, metody resymbolizacji, kreowanie środowiska komunikacji, puste znaczace

Resymbolizacja ustalonego doświadczenia społecznego towarzyszy, a czasem nawet wyprzedza każde znaczące zmiany społeczne. Sytuacja ostatnich dziesięcioleci dla wielu krajów byłego obozu socjalistycznego jest związana z - niekiedy dramatycznymi - próbami przewartościowania systemów istniejących znaczeń, a także mechanizmów ich podtrzymania i odtwarzania. Krytycznej refleksji podlegają przede wszystkim «ikony» socjalistycznego stylu - reprezentacje ideologiczne ${ }^{1}$, które muszą teraz na nowo zdać egzamin z atrakcyjności i ponadczasowej adekwatności. Tocząca się we wspólnotach postsocjalistycznych dyskusja o dziedzictwie kulturowym podzieliła jej uczestników na «ikonofo-

\footnotetext{
1 Pod pojęciem ideologii rozumiem ,zestaw zaleceń do zajęcia pozycji w świecie współczesnej praktyki społecznej oraz działania zgodnie z nią (albo zmieniać świat, albo utrwalać w jego dzisiejszym stanie)" (Уайт 2002: 42).
} 
bów» (iconophobia) i «ikonofilów» (iconophilia) (za: Mitchell 2005: 93). Pierwsi z nich dążą do dyskursywnego wypierania kodów minionej kultury, podczas gdy drudzy pracują nad ich „ekshumacją” i ,reanimacją”. W wierności literze i duchu tradycji socjalistycznej ikonofile widzą warunek zachowania dziedzictwa kulturowego. W tej walce semiotycznej bierze udział również edukacja.

Problem resymbolizacji polega głównie na tym, że doświadczenie, na które zwrócona została uwaga oponentów, nie istnieje obecnie w takim kształcie, w jakim zostało stworzone przez jego inicjatorów. Wszystko, czym dysponują strony konfliktu - to teksty, interpretujące tradycję w taki lub inny sposób, praktyki ich dekodowania oraz kreacje i krytyka, związane z samostanowieniem narratora ${ }^{2}$. Wypowiedzi na temat tradycji mówią więcej o ideologii użytkownika tekstu, niż o «prawdzie» doświadczenia. $Z$ tego punktu widzenia myśl o tradycji jest raczej autoreferentna, czyli odsyła nie tyle do zawartości wyrażenia, ile do jego początkowych warunków: zatwierdzanej rzeczywistości, jawnych i ukrytych kontekstów, wzorców zachowania i świadomości. W takim stopniu, w jakim praktyka intepretowania tradycji zyskuje uznanie społeczne, ikonofoby lub ikonofile otrzymują szansę uczestniczenia w procesach kulturowych, a co za tym idzie - możliwości wpływu społecznego. Oczywiście, nie jest on absolutny i zależy od wielu towarzyszących mu okoliczności, na przykład: polityki państwowej, dynamiki sytuacji, stanu myśli humanistycznej, wrażliwości publicznej. Jednak to uwarunkowanie resymbolizacji nie wyklucza, ale nawet wzmacnia symboliczną walkę konstrukcji dyskursywnych, będących przedmiotem analizy w niniejszym tekście.

W artykule stawiam sobie za cel, po pierwsze: wzięcie udziału w procesach postsocjalistycznej resymbolizacji fundamentów edukacyjnych, a po drugie: odczytanie tradycji pedagogicznej w kontekście „symbolicznego logosu edukacji” (zob. Schulz 2009: 214). Oznacza to, że rozważania nie będą dotyczyły kontekstów pozatekstowych, lecz interpretacji tekstu pedagogicznego, prowadzącej do odczytania praktyki doświadczania tradycji oraz konsekwencji, które wynikają z intertekstualnego oddziaływania w lokalnym akcie resymbolizacji. Moim zamiarem nie jest udzielenie odpowiedzi na wszystkie możliwe pytania, a raczej to, by (parafrazując G. Deleuze'a) konstytuować problemy związane $z$ sensem i tworzyć pojęcia zmuszające do zmierzania w kierunku rozumienia i rozwiązania problemów.

\section{Doświadczenia pedagogiczne A.S. Makarenki w perspektywie «ikonofobii» $\mathbf{i}$ «ikonofilii»}

$\mathrm{Na}$ wstępie dokonam niewielkiego metodycznego uściślenia. Dotyczy ono gry słów, w którą włączane będą różne fragmenty analizowanego dyskursu pedagogicznego. Będzie ona polegała na tym, żeby pobudzić wypowiedź do działania nie według reguł se-

2 Idea narracyjnej więzi opiera się na założeniu, ,że proces rozumienia ma charakter konstrukcyjny, a nie reprodukcyjny (...) Innymi słowy, rzeczywistość nie jest odzwierciedlana, lecz konstruowana i wielokrotnie rekonstruowana w umyśle jednostki” (Klus-Stańska 2002: 191). 
mantycznych, lecz pragmatycznych. Będzie mnie więc interesowało to, w jaki sposób eksponuje się doświadczenie A.S. Makarenki, jak wpisuje się ono w kontekst teoretyczny lub praktyczny, oraz w jaki sposób «warunkowy Makarenko» jest oddziałuje na kierunek zmian społecznych i oświatowych. Regulatorem «pragmatycznego zwrotu» będzie znana wypowiedź R. Rorty'ego o tym, że postęp wiedzy humanistycznej trzeba rozpatrywać nie z punktu widzenia rozumienia tego, jakie są rzeczy naprawdę, ale jako «historię pożytecznych metafor» (Рорти 1996: 30). Oznacza to, że w centrum zainteresowania prowadzonych analiz znajdą się przede wszystkim te konteksty narracyjne, z których korzystają ikonofile i ikonofoby, resymbolizując obraz praktyki A.S. Makarenki. Wśród narracyjnych chwytów ikonofilów, realizowanych na tle ogólnej strategii sakralizacji, wyodrębniają się trzy powiązane ze sobą taktyki: tautologia, dekontekstualizacja, asymilacja.

\section{Tautologia}

Interpretator omalże dosłownie odtwarza wypowiedzi samego A.S. Makarenki, potwierdzając na przykład, że:

(...) rozpatrywał kolektyw jako organiczną cząstkę społeczeństwa, uznając go za główny instrument wychowania (...). Formująca funkcja kolektywu wyraża się tym, że jego członkowie występują jako aktywne podmioty społecznie znaczącej działalności kolektywnej i wzajemnych relacji (...). Współczesna nauka pedagogiczna wciąż rozwija teorię wychowania kolektywnego (Комарова 2014: 129).

W wypowiedzi tej fenomeny «kolektyw» $\mathrm{i}$ «kolektywny» nie podlegają analizie, lecz są prezentowane jako ponadczasowe i oczywiste wartości. Hiperocena Makarenki jako «wielkiego pedagoga» ma na celu na zapewnienie odpowiedniej symbolicznej identyfikacji z tym obrazem. Tautologia w analizowanym cytacie nie tylko pokazuje bezkrytyczną niezmienność ważnych dla interpretatora znaczeń, ale i usuwa samą konieczność krytyki, ponieważ funkcja została już podjęta przez «współczesną nauką pedagogiczną». W efekcie chwyt tautulogiczny staje się narzędziem przymusu symbolicznego i panowania nad adresatem tekstu. Paradoksalnie, nie mniejsze znaczenie dla praktyki ikonofilów ma unikanie konkretyzacji znaczenia. Formalizm tautulogicznej tezy wytwarza alienację u czytającego, co z kolei, zapewnia «wieczne» istnienie warunkowego «Makarenki» jako «martwego» symbolu (światła dawno zgasłej gwiazdy).

\section{Dekontekstualizacja}

Pedagogika A.S. Makarenki, wyrastająca z lokalnego kontekstu kulturalno-historycznego, uniwersalizuje się, pojawia się jako absolutne dobro. Przypisuje się jej wysoki potencjał etyczny (status programu rozwoju osobowości), który zarazem jest estetyzowany, przybierając znamiona doskonałej formy artystycznej:

„Chciałoby się w związku z tym zwrócić szczególną uwagę na to, że A.S. Makarenko, formułując cel wychowania, ogarnia całe bogactwo stosunków człowieka ze światem, ich wewnętrzne piękno, indywidualistyczne i odrębne połączenie istotnych cech oraz właści- 
wości, które ukazują się w zachowaniu, czynach i działaniach. Jest to punkt wyjścia programu istoty ludzkiej, w nim nie tylko mądrość pedagogiczna, ale i bezsprzeczne piękno zasad pedagogicznych" (Ахияров 2003: 51).

Dekontekstualizacja może przybierać również romantyczny kształt, dzięki czemu doświadczenie Makarenki jawi się jako ponadczasowe dobro, przedmiot prostej ciągłości i dosłownego odtworzenia. W poetyckich narracjach ikonofilów Makarenkowska tradycja jest ukazana jako znaczący wkład do światowej pedagogiki:

(...) oparta jest na humanistycznych założeniach, przemawiających do ludzi na całym świecie, wyzwalających w nich wiarę w człowieka i możliwości wychowania; rozwija i wzbogaca nową technikę pedagogiczną, umożliwiającą skuteczne oddziaływanie na jednostkę, grupę i większą zbiorowość (Lewin, 1986, s. 138).

Tu powstaje jeszcze jeden paradoks. Zdekontekstualizowany fenomen nie przekształca się w abstrakcję wyższego rzędu, lecz w trakcie wielokrotnego powtórzenia naturalizuje się, znajdując quasi-fizyczne, autonomiczne formy istnienia. $\mathrm{Z}$ tego punktu widzenia dekontekstualizacja staje się podstawą reifikacji fenomenów edukacyjnych" (Бергер 1995: 147) i zarazem mechanizmem ich konserwacji w dyskursie.

Asymilacja

Doświadczenie Makarenki narrator łączy się ze znanymi sobie humanistycznymi fenomenami. Rozpoznaje to doświadczenie w odniesieniu do istniejących matryc myślowych, absorbując przy tym ich właściwości. Nieznane określa za pomocą znanego:

(...) widzimy (...) podobieństwo z grupą-T: community self-survey, którą określa się jako „samobadający się ogół”. W tych samych celach Makarenko stworzył też inny bardzo skuteczny model - równoległego oddziaływania na osobę (Меттини 2010).

W asocjowaniu znikają właściwości pedagogicznych i terapeutycznych praktyk, a społeczna rzeczywistość przybiera kształt homogenicznego środowiska. Bezpośrednim efektem działania tak zorganizowanych wypowiedzi staje się nieczułość odbiorcy tekstu wobec odmienności.

Najważniejszą właściwością stylu tekstu ikonofilów jest realizm narracyjny (Анкерсмит 2002: 118). Ta technika ustala relację podporządkowania między znaczącym i znaczonym, w której znaczące jest drugoplanowe wobec znaczonego. Znaczące narracyjnego realisty ma odzwierciedlać swój przedmiot, a im ściślejszy jest ich związek, tym prawdziwszy jest wynik syntezy interakcji elementów znaku - pojęcie. Dla tego stylu pisania naturalne jest pytanie o to, jakie naprawdę było doświadczenie Makarenki. Fetyszyzacja pozatekstowej rzeczywistości - alfa i omega realistycznej narracji, oraz umowność znaku: nawet jeśli realista formalnie przyjmuje tę tezę, w praktyce nie ma ona żadnej wartości dla jego działań. 
Strategią ikonofobów jest desakralizacja «ikony», co w praktyce wyraża się krytyką, czyli demaskowaniem konstrukcji ikonofilów jako fałszywych, a samego konstruowania jako zaangażowanego albo po prostu bezpodstawnego działania. Atakowanie symbolu w desakralizacyjnym kontekście występuje na kilku płaszczyznach: dotyczy zarówno spójnego symbolicznego systemu, jak i oddzielnych atrybutów. W poniższej analizie ujawniam kilka taktyk narracyjnych: renominację, przewartościowanie, archiwizację.

Renominacja ma z reguły holistyczną orientację i zmierza do obniżenia statusu symbolu, jego zdegradowaniem do rangi znaku:

(...) mówić o jakimś szczególnym systemie Makarenki, jako wcieleniu oryginalnej koncepcji pedagogicznej się nie godzi (...). (...) jeśli autor w najbardziej znaczącym, jak przyjęto uważać, dziele praktycznie nic nie mówi o procesie wychowawczym, czy właściwe jest nazywać go wybitnym pedagogiem XX wieku? (Возчиков 2008: 90).

(...) Makarenko - nie jest pedagogiem, więcej - nie jest wybitnym pedagogiem, jest technologiem, energicznym organizatorem, co samo w sobie nie jest złe, w każdym razie - być technologiem-praktykiem - jest zadaniem nie mniej potrzebnym niż praca pedagoga-nowatora (tamże: 93).

(...) wybitny pedagog Anton Makarenko — jeden z mitów heroicznej (bez ironii!) epoki radzieckiej (tamże: 100).

W indywidualnych przypadkach renominacja jest realizowana nie przez obniżenie semiotycznego statusu symbolu, ale jako umacnianie antysymbolu. W tej perspektywie Makarenko pojawia się jako ,idol państwowo-totalitarnej i autokratycznie-komunistycznej pedagogiki" (Bybluk 2003: 119).

Renominacja, zorientowana na obniżenie statusu symbolu, unieważnia starą prawdę i utwierdza nową. Będąc wyrazem całościowego podejścia do przewartościowania obiektu, okazuje się ona czynnikiem reorganizującym wszystkie relacje strukturalne w symbolicznym obszarze starego symbolu. Wpływ takiego rodzaju narracji na odbiorcę jest tym większy, im silniejsza jest jego identyfikacja z symboliczną przeszłością. Renominujący tekst $\mathrm{z}$ tego punktu widzenia pragnie oddziaływać tak, jak działa semiotyczna maszyna alternacji (Бергер 1995: 257), modyfikująca świadomość czytelnika.

Przewartościowanie może dotyczyć oddzielnych składników symbolicznego doświadczenia. Tu realizuje się ono jak roszada dwóch argumentów, ponieważ znak $(+)$ zmienia się na znak (-). W.A. Suchomliński, nazywając siebie uczniem A.S. Makarenki i wysoko oceniając jego działalność, pisze:

Wychowanie będzie deficytowe, jeżeli to zespoły staną się celem wychowania. Cel wychowania - człowiek, wszechstronnie rozwinięta osoba, zespół - środek wychowania (Сухомлинский 1989: 74). 
Moc działania zespołu jest bezsprzeczna. Ale przeciwstawiać «równoległe działanie» bezpośredniemu działaniu pedagoga na wychowanka - to w istocie przeczyć pedagogice (tamże: 75).

Nie ma wątpliwości, że jedną z najważniejszych cech, które wychowujemy u człowieka jest zdyscyplinowanie. Ale uważać, że dyscyplina to tylko rezultat wychowania - oznacza zamknąć oczy na to, co robi się w szkole. Dyscyplina - to przede wszystkim środek wychowania, i tylko potem - rezultat wychowania (tamże: 77).

Przewartościowując działalność A.S. Makarenki oraz wypominając mu brak zainteresowania osobą wychowanka i jednością duchową nauczyciela i ucznia, W.A. Suchomliński jednocześnie potwierdza prawo pedagoga do interwencji w świat wewnętrzny dziecka, która to interwencja z kolei jest niemożliwa bez idealizacji obrazu pedagogicznego i identyfikacji (w rozumieniu Freuda) wychowanka z tym obrazem.

Archiwizacja jako chwyt narracyjny jest zgodna z pojmowaniem tradycji jako historycznie przezwyciężonej praktyki. W przypadku Makarenki wyraża się to w zamknięciu jego twórczości w ramach radzieckiego (socjalistycznego) projektu, stworzonego, by niszczyć humanistyczne pedagogiczne nadzieje. Autor uważa, że w pewnym okresie rosyjskiej historii nastąpiło odejście

(...) od idei swobodnego wychowania i psychologicznych podstaw edukacji na rzecz powrotu do pedagogiki, u której źródeł znajdowały się prace Uszyńskiego, Makarenki i Stalina. Ideałem stała się odtąd klasa w pełni kontrolowana przez nauczyciela, który miał w niej odgrywać główną rolę (Kadykało 2012: 90).

Zgadza się z nim również inny uczony:

Teleologia wychowawcza zakorzenia się w ideologii komunistycznej. Przykłady można by mnożyć, począwszy od tekstu Makarenki Cele wychowania, w którym autor wskazuje, na co w warunkach rzeczywistości komunistycznej powinno być ukierunkowana praca wychowawcza (Kołakowski 2012: 130).

I jeśli archiwizacja $\mathrm{w}$ przedstawionych powyżej cytatach spełnia się $\mathrm{w}$ rozumieniu negatywnym i sprawia, że zwrócenie się do tradycji pedagogicznej jako zasobu rozwoju staje się problematyczne, to i pozytywna archiwizacja, o której świadczy poniższa wypowiedź, w swoich skutkach - co dziwić nie powinno - będzie zrozumiana analogicznie:

(...) pedagogiczne nowatorskie doświadczenie Makarenki było urzeczywistnione właśnie w ZSRR, właśnie w warunkach układu radzieckiego, kiedy idea zespołu, kolektywizmu, odpowiedzialności, obywatelskiej postawy były pożądane w mniemaniu opinii publicznej większości populacji kraju. W warunkach systemu kapitalistycznego, nawet na poziomie eksperymentu, na poziomie systemu podobna pedagogiczna działalność jest niemożliwa. Sam Makarenko nigdy nie rezygnował ze społecznego osadzenia swojego doświadczenia w radzieckim systemie (Быков 2013: 21-22). 
W bardziej radykalnej wersji archiwizacji doświadczenie A.S. Makarenki niebezpiecznie zbliża się do struktur «tajnej policji», gdzie on nie tylko służył’ lecz również korzystał z pokrewieństwa z W.A. Balickim, kierownikiem GPU-NKWD Ukrainy, organizatorem masowego terroru. Autor tej wersji archiwizacji, niemiecki filozof edukacji G. Hilling, w taki sposób określa kontekst swojego badania:

Jak to możliwe, że Makarence - który nie był ani współpracownikiem GPU, ani nawet członkiem partii komunistycznej - została jesienią 1927 r. powierzona komuna im. F.E. Dzierżyńskiego? Kto rekomendował Makarenkę do tej pracy, kto powierzył mu stanowisko kierownika? Dlaczego nie zginął w Charkowie, wtedy stolicy Ukrainy, i później w nowej stolicy - Kijowie, dokąd był przewieziony w 1935 roku na trzeciorzędne stanowisko w aparacie GPU-NKWD, do czasu aż w lutym 1937 r. nie udało mu się przeprowadzić się do Moskwy i w ten sposób uratować się od terroru na Ukrainie? (Хиллиг 2005: 65).

Ta wersja archiwizacji jest ciekawa pod wieloma względami. Po pierwsze, z powodu intrygi, skupiającej uwagę czytelników na biograficznych szczegółach życia A.S. Makarenki. Biografia w tym przypadku jest narracją, w której cieniu ukrywa się rzeczywista tradycja pedagogiczna. A po drugie, ze względu na ukierunkowanie archiwizacji na przeszłość. Przeszłość stanowi zamkniętą semantyczną enklawę, która jak stłumiona trauma freudowskiego doświadczenia, determinuje teraźniejszość. Uczony oczarowuje czytelnika przeszłością i jej konspiracyjnymi konotacjami. Doświadczenie Makarenki zostaje wyłączone z teraźniejszości, tworząc spójną całość wyłącznie z epoką totalitarną.

W analizie narracyjnych taktyk ikonofilów i ikonofobów ważny jest nie tyle wspomniany przedmiot opisu, co system konstrukcji semiotycznych, za pomocą których dokonuje się jego przewartościowanie. W przytoczonym powyżej cytacie wyodrębniłem kilka par kategorii: zespół-jednostka, równoległe działanie-wzajemne oddziaływanie (interakcja), cel-środek. $Z$ zewnątrz elementy te wyglądają jak przeciwstawne, ale jest to różnica elementarna. Na poziomie systemu języka narracje ikonofilów i ikonofobów są w wysokim stopniu tożsame, ponieważ pretendują do roli Wielkiej Narracji, zdolnej dokonać uniwersalnej syntezy wszystkich dyskursów, które znajdują się w ich obszarze. Jest przy tym oczywiste, że sama Wielka Narracja obdarzona jest znamionami prawdziwości, współczesności i postępu. Legitymizując sama siebie, przenosi się do transcendentnej przestrzeni i z jej lokując się w niej, stwarza obraz «prawdziwego stanu» rzeczy w pedagogice. W wyniku takiego rodzaju uprzedmiotowienia edukacji sam system języka jest taki sam, co oznacza, że pomimo kontrowersji między ikonofilami i ikonofobami (albo nawet dzięki niej), realia edukacji zostają zachowane. To jest paradoks. Zmieniający się świat wymaga dynamicznej, wrażliwej na zmiany formy edukacji, a ikonofile i ikonofoby wspierają dyskurs niezmienności.

\footnotetext{
3 W 1927 roku dziecięca kolonia, w której pracował A.S. Makarenko, była przekazana na podstawie jego podania z systemu Ludowego Komisariatu Edukacji Ukrainy do GPU.
} 


\section{Pedagogika A.S. Makarenki jako praktyka symboliczna}

Ideę języka deskryptywnego, który pozwoliłby odkryć produktywny potencjał praktyki A.S. Makarenki, zaczerpnąłem z artykułu W. Siegienia: Od Dzierżyńskiego do Magnitskiego i z powrotem. Studium dzieciństwa i sieroctwa w rosyjskiej polityce symbolu (2015), w którym autor analizuje stosunki państwa totalitarnego i edukacji oraz pokazuje, jak za pomocą symbolicznego dyktatu władza polityczna znacznie ogranicza refrakсуjność edukacji (Бурдье 2001a: 52) i zmienia ją w maszynę indoktrynacji podmiotów. W. Siegień opisuje mechanizm tego dyktatu, związanego z przymusem narracyjnym oraz tworzeniem i rozpowszechnieniem w przestrzeni publicznej różnego rodzaju opowiadań mitologicznych („fabuł mitycznych”), co pozwala władzy „połączyć i ponownie nadać sens wątkom (ideom politycznym, wydarzeniom czy postaciom), które rozpatrywane poza kontekstem danej opowieści są ze sobą sprzeczne lub ambiwalentne wobec siebie" (Siegień 2015: 127). Z tego punktu widzenia władza zainteresowana jest pewnym zestawem wersji rzeczywistości, w tym też alternatywnych, za pomocą których może manipulować świadomością społeczną, zachowując kontrolę nad sytuacją i stwarzając wrażenie zmian ${ }^{4}$. Opisując politykę symboliczną państwa radzieckiego w edukacji W. Siegień posługuje się językiem współczesnej filozofii i socjologii, ,pobudzając” w ten sposób do rozwoju zwykłe kategorie języka pedagogicznego.

Wykorzystując tę technikę, spróbuję rozważyć symboliczną praktykę A.S. Makarenki jako integralny element edukacji, jako moment jej wewnętrznej produktywności i efektywności społecznej. W tym celu sięgnę do teorii kapitału symbolicznego, sformułowanej przez P. Bourdieu i jego zwolenników. W pracy Reguly sztuki. Geneza i struktura pola literackiego (Les Règles de l'art. Genèse et structure du champ littéraire) Bourdieu wprowadził dwa moim zdaniem - przydatne dla analizy praktyki symbolicznej Makarenki pojęcia: illusio i nomos. Pierwsze z nich związane jest ze zdolnością pola do szczególnej produktywności

w sensie inwestowania w grę, które ratuje agentów od obojętności i pobudza do rozróżniania istotnego z punktu widzenia logiki pola... Prawdą jest również to, że określona forma uczestnictwa w grze, wiara w grę i w wartość stawek (gry), która zapewnia atrakcyjność gry, jest praprzyczyną działania gry i że interes agentów w illusio jest podstawą konkurencji, która przeciwstawia agentów i zapewnia samą grę. Krótko mówiąc, illusio staje się warunkiem funkcjonowania gry i częściowo jej produktem (Bourdieu 1998: 373).

Innymi słowy - illusio jest stawką, ze względu na którą jednostki rozpoczynają komunikację. Istotne jest tu kilka aspektów. Przede wszystkim illusio jest przekonaniem społecznym, czyli warunkiem funkcjonowania tożsamości grupowej. Jego właściwością jest

4 Tak w jednej z niedawno opublikowanych rozpraw rosyjskich naukowców opisane są taktyki władzy wobec edukacji, wykorzystujące obrazy A.S. Makarenki i W.A. Suchomlińskiego. Państwo radzieckie postawiło przed naukowcami, w drugiej połowie lat 50., zadanie sformułowania nowej polityki edukacyjnej, uwzględniającej „zwrot do człowieka jako jednostki”, co zaowocowało wzrostem publikacji naukowych związanych z tym zamówieniem (Кукулин 2015: 320). 
szczególna ,atrakcyjność”, zdolność bycia kuszącą, wywoływania czegoś, co René Girard (uibk.ac.at) nazwał ,pragnieniem mimetycznym” (mimetic desire) - pragnieniem tego, czego chcą inni. Geneza ilusio jest ponadto uwarunkowana stanem komunikacji i nie jest indywidualnym produktem uczestniczących w niej. Zaś bułgarski socjolog D. Deyanov zwraca uwagę, że „to, co w illusio przeżywa się jak oczywistość, jest iluzją dla tego, kto nie odczuwa tej oczywistości” (Деянов 2001: 106).

Drugie pojęcie, czyli nomos, Bourdieu (1998) określa jako „fundamentalne prawo pola, zasadę wizji i dzielenia" (tamże: 365). Nomos, mimo semantycznej bliskości z prawem, przyjmuje za obszar swojej referencji nie zewnętrzny, lecz wewnętrzny porządek, który jednak nie ma „absolutnej niezależności od regulacji zewnętrznej” (Бурдье 2001: 115). Nomos jest wykorzystywany do oznaczenia ,głównej, obiektywnej zasady praktyki w określonej dziedzinie. W gospodarce kapitalistycznej będzie to «zysk», w dziedzinie sztuki «czysta sztuka», w polityce - «panowanie»" (Schäfer 2009). Przeznaczenie nomosu to związywanie „doświadczenia praktyki i doświadczenia pola” (Ball bd.) oraz podział struktur kognitywnych i oceniających, będących „podstawą nie tylko logicznego, ale również moralnego konformizmu - milczącego porozumienia, przedrefleksyjnego i bezpośredniego - w stosunku do percepcji świata, które jest początkiem doświadczania świata jako świata zdrowego rozsądku” (Бурдье 2007a: 243). Ważną cechą wyróżniającą nomos jest jego nieeksplikowany domyślny status.

Umieszczenie pedagogicznego doświadczenia A.S. Makarenki w kontekście koncepcji symbolicznej P. Bourdieu pozwala zobaczyć je inaczej niż przedstawiają to narracje ikonofobów i ikonofilów. Posłużenie się nią oznacza zmianę optyki badawczej, co rozważę na przykładzie analizy fragmentu „Poematu pedagogicznego”:

Prawie bez trudu udało się nam - zamiast skromnych ideałów szewca - postawić na czele emocjonujące i piękne znaki. W tych czasach słowo „rabfak” (fakultet robotniczy) nie oznaczało wcale tego, co teraz oznacza. Teraz to prosta nazwa skromnej instytucji edukacyjnej. Wtedy to był sztandar wyzwolenia młodzieży robotniczej z ciemnoty i ignorancji. Wtedy to było strasznie jaskrawe potwierdzenie niezwykłych praw człowieka do wiedzy, i wtedy my wszyscy odnosiliśmy się do rabfaka, szczerze mówiąc, z pewnym nawet rozczuleniem (Макаренко 1984: 178).

Jeden z utytułowanych rosyjskich oponentów Makarenki pisze w związku z tym następująco:

(...) w kolonii... dawano tylko wykształcenie podstawowe, i sądząc po wszystkim, na rabfak trafiały jednostki, które potrafiły wykonać jakieś zadania z języka rosyjskiego i arytmetyki (...) zdecydowana większość kolonistów nie miała wiedzy odpowiadającej wykształceniu podstawowemu. Liczba tych, którzy wstąpili, była nieznaczna w stosunku do ogólnej liczby kolonistów (Возчиков 2008: 89).

W komentarzu nacisk postawiony jest na słowo rabfak, za pośrednictwem którego ujawnia się utopijność pedagogicznych celów nakreślonych przez Makarenkę. Proponuję zatem odczytać cytat z „Poematu pedagogicznego” w inny sposób, z podkreśleniem fragmentów: 
„postawić na czele emocjonujące i piękne znaki”, „sztandar wyzwolenia młodzieży robotniczej z ciemnoty i ignorancji”, „my wszyscy odnosiliśmy się do rabfaka, szczerze mówiąc, z pewnym nawet rozczuleniem".

Rabfak jako „emocjonujące i piękne znaki” (!). Wydaje mi się, że wyodrębnione słowa wskazują na specyficzną społeczną konstrukcję illusio. Dla semiotycznego obiektu tego typu nie ma znaczenia kryterium, które wykorzystuje oponent Makarenki. Illusio jest formą utopijną i jej znaczenia będą zgodne, po pierwsze - z potencjałem mobilizującym, a po drugie - ze zdolnością łączenia horyzontów bieżących działań z odległą przyszłością. Rabfak z tego punktu widzenia to marzenie społeczności kolonistów, siła wznosząca ich ponad powszedniość, symbol nadający ich wysiłkom sens ,jutrzejszej radości”.

Bez uwzględnienia roli illusio, ,podniosłości” kontekstualizującej struktury nomosa: dyscyplinę, zmianę liderów, stosunki pracy, współzależność w kolektywie i inne, doświadczenie Makarenki nabywa wyłącznie cech mechanicznych, stając się „łatwą zdobyczą” ikonofobów lub przedmiotem mistyfikacji ikonofilów. Należy przy tym przyjąć, że rabfak jako illusio nie jest indywidualnym wytworem A.S. Makarenki. Nieprzypadkowo pisze on, że „wszyscy odnosiliśmy się do rabfaka ... z pewnym nawet rozczuleniem”. Tymi słowami określa społeczną genezę rabfaka-illusio i jego związek ze zbiorową wyobraźnią.

Życie konkretnego illusio jest krótkie. Konieczność jego zamiany (resymbolizacji) jest uwarunkowana z jednej strony, rutynizacją, integralną częścią procesu reprodukcji pedagogicznej (Бурдье 2007: 68-69), a z drugiej utratą jakości horyzontu, przekształceniem obiektu symbolicznego w możliwy do osiągnięcia pragmatyczny cel. W tym kontekście należy rozpatrywać też przeniesienie kolonii im. M. Gorkiego na Kuriaż, stworzenie projektu pedagogicznego - komuny im. F.E. Dzierżyńskiego - oraz jej zagładę w końcu lat 30. Zrozumiałe jest również to, że materiałem do produkcji illusio są popularne przekonania danej epoki, poddawane specjalnej aranżacji pedagogicznej. Sens tej aranżacji można wyjaśnić, odwołując się do opracowań T. Szkudlarka. Opierając się na rozprawach filozofa E. Laclau, Szkudlarek (2008: 134) wprowadza pojęcie puste znaczace. Puste, jak przypuszczam, jest zgodne z jego formalnym statusem, możliwością bycia miejscem projekcji wyobraźni zbiorowej i indywidualnej, zbiornikiem intencji członków wspólnoty symbolicznej. Z pozycji naukowego wymogu określoności pojęć taka właściwość konstrukcyjna pustego znaczacego jest postrzegana jako poważny defekt konceptualizacji. Ale o to właśnie chodzi, że illusio jest kategorią nie teoretyczną, lecz praktyczną. Jej przekształcenie $\mathrm{z}$ formy metaforycznej do pojęciowej prowadzi do utraty funkcji roboczej.

W logice praktyki symbolicznej w centrum uwagi pedagogicznej nie znajduje się osoba wychowanka i nawet nie zespół, chociaż sam Makarenko niekiedy nalega na to ${ }^{5}$, lecz środowisko interakcji oraz zachodzące się w nim procesy i efekty. Pedagog z tego punktu widzenia jest kreatorem środowiska komunikacji i na tym polega jego podstawowa misja edukacyjna. Na wynalezieniu i zaaprobowaniu modeli pedagogiki jako praktyki symbolicznej, polega, moim zdaniem, nieprzemijające znaczenie i aktualność doświadczenia pedagogicznego A.S. Makarenki.

5 Tutaj jestem zmuszony wystąpić przeciw Makarence za Makarenką. 


\section{Zakończenie}

Podsumowując rozważania, chciałbym skupić się na dwóch aspektach związanych z epistemologią edukacji. Pierwszy dotyczy analizy dyskursu pedagogicznego, który, jak próbowałem pokazać, podporządkowany jest logice nie tyle naukowej, ile praktycznej. To znaczy, że do studiowania dyskursu edukacji nie powinny być stosowane kryteria korespondencji prawdy, systemowa spójność i kompletność, lecz wskaźniki funkcjonalności i efektywności, sytuacyjności i lokalności. Oznacza to powrót do znanego postulatu sformułowanego przez ojca amerykańskiego pragmatyzmu W. Jamesa, zgodnie z którym - analizując wypowiedź pedagogiczną ,powinniśmy tylko określić ten sposób działania (conduct), który zdolna jest ona spowodować: na tym sposobie działania opierają się właśnie wszystkie znaczenia tej wypowiedzi” (Джеймс 1997: 225).

Drugi aspekt związany jest ze statusem niniejszego artykułu i stosunkiem do niego. Nie chciałbym, aby postrzegano go w kategoriach głoszenia nowej prawdy ${ }^{6}$, legitymizującej jedynie prawidłowe rozumienie doświadczenia pedagogicznego A.S. Makarenki ${ }^{7}$. Chodzi tu wyłącznie o eksperyment lingwistyczny, budowę lokalnej „,społeczno-konstruktywistycznej" interpretacji, zademonstrowanie możliwości odnowy języka opisów pedagogicznych na drodze dołączania do nich zasobu kategorialnego innych dyscyplin humanistycznych, a z drugiej - o zaktywowanie nowego odczytania twórczości A.S. Makarenki. Ten potencjał może być pożyteczny w sytuacji postsocjalistycznej, dla której właściwe są „dążenia do skrajnego indywidualizmu, wyrastające z doświadczeń tzw. dzikiego kapitalizmu" (Siegień 2015: 125), a jego obecność szczególnie widoczna jest w regionie postradzieckim w formie kryzysu celów wychowania. Innej przesłanki zwrócenia się ku doświadczeniom Makarenki jako praktyce symbolicznej dostarcza pytanie o tworzące się wzajemnie wspólnoty epoki cyfrowej. Szczególnej wagi nabiera problem obecności w edukacji jednostek zdolnych działać w trybie „tworzenia społeczności uczących się kooperatywnie, aż po różnorodne formy oddolnego wytwarzania wiedzy i udostępnianie jej innym” (Klus-Stańska 2013: 10).

\section{Literatura}

Ball S.J., Bourdieu's Method. An Exposition and Application, http://deptedu.ccu.edu.tw/blog/ file/090508ball.ppt.

Bieszcad B. (2013), Pedagogika i język. Perspektywa ponowoczesna. Kraków, Wydawnictwo Uniwersytetu Jagiellońskiego.

Bourdieu P. (1992), Les Règles de l'art. Genèse et structure du champ littéraire. Paris, Éditions du Seuil.

Bybluk M. (2003), Przemiany demokratyczne edukacji w Rosji: studia i szkice historyczno-pedagogiczne. Kraków, Oficyna Wydawnicza Impuls.

\footnotetext{
6 Kierowałem się założeniem, że „Prawda jest zatem co najwyżej konstrukcją lingwistyczna, ujmowaną nominalistycznie, wyłącznie w kategoriach lokalnie prowadzonego dyskursu” (Bieszcad 2013: 32).

7 Parafrazując słowa D. Klus-Stańskiej, nie zamierzam przekonywać czytelnika o tym, że pedagogika w rzeczywistości jest taka, ale proponuję „,tak na nią spojrzeć” (por. Klus-Stańska 2010: 18).
} 
Girard R., Eating Disorders and Mimetic Desire. http://uibk.ac.at/theol/cover/contagion/contagion3/contagion03_girard.pdf.

Kadykało A. (2012), Dzieciństwo jako rosyjski temat kulturowy w XX wieku, (rozprawa doktorska, mps), Uniwersytet Warszawski, Wydział Artes Liberales.

Klus-Stańska D. (2013), Cyfrowi tubylcy w szkole cyfrowych imigrantów, czyli awatar w świecie Ptysia i Balbinki. „Problemy Wczesnej Edukacji”, nr 4 (23).

Klus-Stańska D. (2010), Dydaktyka wobec chaosu pojęć i zdarzeń Warszawa, Wydawnictwo Akademickie Żak.

Klus-Stańska D. (2002), Narracje w szkole. W: J. Trzebiński (red.), Narracja jako sposób rozumienia świata. Gdańsk, Gdańskie Wydawnictwo Psychologiczne.

Lewin A. (1986), Tryptyk pedagogiczny: Korczak-Makarenko - Freinet. Warszawa, NK.

Mitchell W.J.T. (2005), What Do Pictures Want? The Lives and Loves of Images. Chicago, University of Chicago Press.

Schäfer H., Seibert L., Hahne P., Tovar A, Stockmeier A., Bourdieu's Categories for «Field» Construction, https://www.uni-bielefeld.de/theologie/CIRRuS-downloads/Schaefer-ea_2009_CIRRuS_field-categories.pdf.

Schulz P. (2009), Wykłady z pedagogiki ogólnej. T. 3. Logos edukacji. Toruń, Wydawnictwo Naukowe UMK.

Siegień W. (2015), Od Dzierżyńskiego do Magnitskiego i z powrotem. Studium dzieciństwa i sieroctwa w rosyjskiej polityce symboli Społeczeństwo. „Studia Pedagogiczne” LXVIII Dzieciństwo i wczesna edukacja: kontrowersje, problemy i poszukiwania.

Szkudlarek T. (2008), Dyskursywna konstrukcja podmiotowości. „Puste znaczace” a pedagogika kultury. „Forum Oświatowe”, numer specjalny.

Анкерсмит Ф.Р. (2003), Нарративная логика. Семантический анализ языка историков. Пер. О. Гавришиной, А. Олейникова, Москва, Идея Пресс.

Ахияров К.Ш. (2003), А.С. Макаренко и современность. Уфа, РИО РУНМЦ МО РБ.

Бергер П. (1995), Социальное конструирование реальности. Трактат по соииологии Знания. Пер. с англ. Е. Руткевич, Москва, Асаdemia-Центр, МЕДИУМ.

Бурдьё П. (2007), Воспроизводство: элементы теории системы образования. Пер. Н.А. Шматко, Москва, Просвещение.

Бурдье П. (2001), Клиническая сочиология поля науки. Пер. Н.А. Шматко, Алетейя, Москва, Санкт-Петербург, „Социоанализ Пьера Бурдье”, Институт экспериментальной социологии.

Бурдье П. (2001а.), Поле политики, поле сочиальных наук, поле журналистики. Пер. Н.А. Шматко, Алетейя, Москва, Санкт-Петербург, „Социоанализ Пьера Бурдье”, Институт экспериментальной социологии.

Бурдье П. (2007a), Социология сочиильного пространства. Пер. Н.А. Шматко и др., Алетейя, Москва, Санкт-Петербург, Институт экспериментальной социологии.

Быков А.К. (2013), А.С. Макаренко: к дискуссии о творческом наследии. „Вестник Московского университета имени С.Ю. Витте”, серия 3: „Педагогика. Психология. Образовательные ресурсы и технологии”, № 1 (2).

Возчиков В.А. (2008), Миф «Педагогической поэмы»». „Общество. Среда. Развитие Теrra Humana”, выпуск № 4.

Деянов Д. (2001), Практические логики и коммуникативные стратегии, „Критика и семиотика", выпуск $3 / 4$. 
Джеймс У. (1997), Воля к вере. Пер. с англ. С.И. Церетели, П.С. Юшкевича, Л.Е. Павловой, М. Гринвальд, Москва, Республика.

Комарова А.В., Слотина Т.В. (2014), Современный взгляд на идеи А.С. Макаренко и И.П. Иванова о взаимосвязи личности и коллектива. „Российский гуманитарный журнал”, т. 3, № 2.

Кукулин И., Майофис М., Сафронов П. (2015), Острова утопии: Педагогическое и социальное проектирование послевоенной школы (1940-1980-е). Москва, Новое Литературное Обозрение.

Макаренко А.С. (1984), Педагогические сочинения. Т. 3, Москва, Педагогика.

Меттини Э., Коллективное воспитание в педагогическом наследии А.С. Макаренко. „Психолого-педагогическое наследие прошлого в современной социально-педагогической деятельности", http://makarenko-museum.ru/news/Ekat/2010/Ekat_2010_20.htm.

Рорти Р. (1996), Случайность, ирония и солидарность. Пер. с англ. И.В. Хестановой, Р.З. Хестанова, Москва, Русское феноменологическое общество.

Сухомлинский В.А. (1989), Идти вперед! „Народное образование”, № 8.

Уайт Х. (2002), Метаистория: историческое воображение в Европе ХІХ в. Пер. с англ. Е.Г. Трубиной, В.В. Харитонова, Екатеринбург, УралГУ.

Хиллиг Г. (2005), А.С. Макаренко и В.А. Балиџкий. Два соратника на службе украинского ГПУ. „Культура народов Причерноморья”, № 62. 